\title{
A Reading of lan McEwan's Saturday: Approaching the Ethical Self by Extending Empathy and Care to the Other in the Post-9/11 Age of Anxiety
}

\author{
Luo Yuan \\ Department of English, Foreign Languages School, Suzhou University of Science and Technology, Suzhou City, China
}

Email address:

yuanluo2002@163.com

\section{To cite this article:}

Luo Yuan. A Reading of Ian McEwan's Saturday: Approaching the Ethical Self by Extending Empathy and Care to the Other in the Post-9/11 Age of Anxiety. International Journal of Literature and Arts. Vol. 9, No. 2, 2021, pp. 46-54. doi: 10.11648/j.ijla.20210902.11

Received: February 24, 2021; Accepted: March 5, 2021; Published: March 17, 2021

\begin{abstract}
Ian McEwan's representative novel Saturday, set on 15 February 2003, the day of the largest protest march against the imminent war on Iraq in London, presents one day in the life of Henry Perowne, a 48-year-old neurosurgeon, holding up to a troubled time in the post-9/11 age of anxiety. From Henry's consciousness the rich narrative weaves the story of his contented and paradoxically happy life together with his anxiety about the terrorism implied in his over-interpretation of the burning airplane in the early morning, his encounter with Baxter in a minor car accident and later Baxter's intruding into his house to endanger his family. Henry Perowne, the privileged neurosurgeon, complacent, and arrogant in his framing life with selected empathy and care for his loved ones, finally awakens to approach his ethical self with responsibility for the Other through extending his empathy and care to the Other represented by Baxter. What Ian McEwan explores in Saturday is an ethical attempt for privileged Westerners to reflect about the deep causes of international terrorism and to sort out the conflicts between self and the Other in an ethical way through extending empathy to more diverse others with the prospect of experiencing profound happiness in the post-9/11 age of anxiety.
\end{abstract}

Keywords: Saturday, Anxiety, Empathy, Ethical Self, Other

\section{Introduction}

Ian McEwan (1948-), is often hailed as the England's greatest living author. He shocked his way onto the literary scene in the 1970s with First Love, Last Rites (1975), his first collection of short stories "that detailed humanity's inherent darkness and complexity. [1]". His interest in the dark themes in the 1970s and early 1980s won him a nickname of Ian "Macabre" [2]. The publication of The Child in Time in 1987 marked the shift of his interest to a broader public reality. So far McEwan has published sixteen novels, with latest Machines Like Me (2019), these works having earned him worldwide critical acclaim and he is generally praised as "the most technically accomplished of all modern British writers [3]". He won the Somerset Maugham Award in 1976 for First Love, Last Rites; the Whitbread Book of the Year Award (1987) for The Child in Time; the 1998 Booker Prize for Fiction for Amsterdam (1998); the National Book Critics' Circle Fiction Award in 2003 for Atonement (2001), the
Paddy Power Political Fiction Book of the Year award in 2012 for Sweet Tooth (2012). McEwan believes that novel is a mode of enquiry into human nature and "imagining what it is like to be someone other than yourself is at the core of our humanity. It is the essence of compassion, and the beginning of morality. [4]" (2001) What he stresses about humanity is empathy. Kohut defines empathy as "the capacity to think and feel oneself into the inner life of another person [5]". Amy Coplan and Peter Goldie point out that empathy are important in at least two aspects. "First, it has been seen as important in relation to our capacity to gain a grasp of the content of other people's mind, and to predict and explain what they will think, feel, and do. And secondly, it has been seen as important in relation to our capacity to respond to others ethically---enabling us not only to gain a grasp of the other's suffering, but also to respond in an ethically appropriate way. [6]" In Ian McEwan's works, various degrees of empathy among characters find expressions in various ways. The relations between deficiency in empathy 
and the emergence of violent behaviour are explored in novels of The Innocent (1990), Black Dogs (1992), The relationship between empathizing with others and the ethical existence of the self is examined in The Child in Time (1987), Atonement (2001) and Saturday (2005). Since the publication of Saturday in 2005, critics have discussed the novel from the perspective of space, intertextuality, politics and consciousness, with little concern about empathy. This paper argues that the protagonist Henry Perowne in Saturday experiences the transformation from a complacent and privileged self with selected empathy and care for his loved ones to extending empathy and care to the Other in the post9/11 age of anxiety, during which he is on the way of approaching his ethical self.

\section{Henry Perowne's Contented Life in the Post 9/11 Age of Anxiety}

Saturday, set on 15 February 2003, the day of the largest protest march against the imminent war on Iraq in London, presents one day in the life of Henry Perowne, a 48-year-old neurosurgeon, belonging to the tradition of modernist 24hour-novels such as James Joyce's Ulysses (1922) and Virginia Woolf's Mrs Dallaway (1925). Like these modernist novels, Saturday explores individual consciousness of the protagonist, Henry Perowne, and a further move from these novels as Dominic Head holds that in Saturday " McEwan is also moving in a new direction, however, trying to produce, perhaps, a diagnostic 'slice-of-mind' novel- working towards the literary equivalent of a CT scan-rather than a modernist 'slice - of-life's novel. [7]'Henry is a expert on human brain, and readers are invited to follow Henry's consciousness to experience his one day life in the contemporary world. Similar to Joe in Enduring Love (1997) and Bernard in Black Dogs (1992), Henry is "an avowed rationalist with firm belief in the meta-narrative of scientific knowledge [8]", which finds expression in the world represented from his consciousness.

The novel begins with Henry's waking at three forty in the early morning on 15 February 2003. At that moment "He doesn't feel tired, despite the hour of his recent labours, nor is his conscience trouble by any recent case. In fact, he's alert and empty-headed and inexplicably elated... And he's entirely himself... [9]" (pp. 1-2) Henry stands at the window, and London city in his eyes and consciousness appears to be progressive and nostalgically optimistic, "That particular facade is a reconstruction, a pastiche---warmtime Fizrovia took some hits from the Lufwaffe---and right behind is the Post Office Tower... a valiant memorial to more optimistic days. [9]" (p. 2) Henry's consciousness and self is closely revealed in the environment and culture in which he grows up. Though London witnessed war, the reconstruction of the city reminds Henry of the old empire with important boosts of glorious days, more optimistic with much strength. Now in the beginning of the twenty first century post-9/11, like many westerners, Henry feels confused, and anxious to some degree, "what days are these? Baffled and fearful, he mostly thinks when he takes time from his weekly round to consider. But he doesn't feel that now. [9]" (p. 3) But now waking from sleep in the early morning, Henry doesn't suffer from anxiety, instead, feels quite elated and views the world positively, proud of the progress of the civilization London has witnessed.

Viewing the buildings outside Henry thinks the city is a success " $a$ brilliant invention, a biological masterpiecemillions teeming around the accumulated and layered achievements of the centuries... And Perowne's own corner, a triumph of congruent proportion... [9]". (p. 3) As a Londonbased neurosurgeon, Henry is contented with his privileged life, with comfortable house located in the urban London center, with successful career and a happy family, with intimate relationships with his wife, Rosolind, a well-known lawyer, their beautiful and talented children, daughter Daisy, an inspiring young poet with a university degree of literature, living in Paris who is expected to come back home at seven in the evening for the family reunion, their son Theo, playing Jazz, also Rosolind's father Grammatical, a famous poet, who is also expected to come back for the family reunion dinner. Watching from the bedroom window, Henry is appreciating the beauty and progress the civilization has achieved "... the pigeon excrement hardened by distance and cold into something almost beautiful, like a scattering of snow. He likes the symmetry of black cast-iron posts and their even darker shadows, the lattice of cobbled gutters. The overall litter baskets suggest abundance rather than squalor... [9]" (p. 3).

Despite the privileged and contented life, Henry's consciousness reveals anxiety and his secured and contented life seems to be fragile in the post- $9 / 11$ age. The $9 / / 11$ terrorists attack not only has greatly traumatized New Yorkers, Americans but also traumatized the people in London, Paris and many other privileged westerners. Fear and anxiety pervade westerners' daily consciousness. Henry is no exception. Henry's self is a part of London. After 9/11, Londoners worry that this city is likely to suffer from the terrorism attack all of a sudden. The information from radio often reminds Henry of the fact that the prosperous and happy life may suddenly perish as those privileged New Yorkers in the twin Towers lost lives unexpectedly and tragically.

Now observing from the window, Henry views something unusual in the sky, "Even as he turns, he's aware of some new element outside, in the square or in the trees, bright but colorless, smeared across his peripheral vision by the movement of his head [8]." (p. 12) He watches an ambulance, siren off, blue lights flashing... First in his eagerness and curiosity, Henry assumes proportions on a planetary scale: it's a meteor burning out in the London sky, traversing left to right, low on the horizon... Then as he hears a rumbling sound and gentle thundering gathering in volume and horrified... The fire must be on the nearside wing... Above the usual deep and airy roar is a straining, choking banshee sound growing in volume-both a scream and a sustained 
shout, an impure, dirty noise that suggests unsustainable mechanical effort beyond the capacity of hardened steel.... [9]" (pp. 13-14) Henry realizes it is a nightmare, with a picture in his mind "... the screaming in the cabin partly muffled by that deadening acoustic, the fumbling in bags for phones and last words, the airline staff in their terror clinging to remembered fragments of procedure... But the scene construed from the outside, from afar like this, is also familiar. It's already almost eighteen months since half the planet watched and watched again, the unseen captives driven through the sky to the slaughter, at which time there gathered round the innocent silhouette of any jet plane a novel association... [9]" (p. 14). The familiar scene 18 months ago just refers to the $9 / 11$ terrorist attack, and the traumatic impact is grave throughout the world, "Everyone agrees, airliners look different in the sky these days, predatory or doomed. [9]" (p. 15) Thus Henry's consciousness reveals an ordinary westerner' fear and anxiety in the post- 9/11 age.

Henry, a specialist on human brain is "an avowed rationalist with firm belief in the metanarrative of scientific knowledge [8]." He tends to interpret the world in his rational way. Now he is interpreting the plane on fire this way, with little empathy. "The fiery white core and its coloured tail have grown larger---no passengers sitting in that central section of the plane could survive... Catastrophe observed from a safe distance. Watching death on a large scale, but seeing no one die. No blood. No creams, no human figures at all, and into this emptiness, the obligation imagination set free [9]. (p. 15) In Henry's mind, what he sees is a great disaster, "It occurs to Perowne that there's something he should be doing [9]" (p. 16) As an experienced doctor, Henry feels it's his duty to respond to the disaster in his professional and responsible way. But quickly his rational thinking justified his giving up responsibility for the strangers, "By the time the emergency services have noted and passed on his call, whatever is to happen will be in the past... perhaps they're already covering the runway in foam. Pointless at this stage to go down and make himself available to the hospital.. Still fifteen miles of descent. If the fuel tanks explode there will be nothing for them to do. [9]" (p. 16) Obviously Henry is trying to excuse his failure to take the ethical responsibility for others. He is reluctant to step out of his sheltered world to help strangers. In his consciousness he further justifies the arbitrariness of catching sight of the accident in midnight, "But a city whose wires never stop singing; among so many millions there are bound to be people staring out of windows when normally they would be asleep. And not the same people every night. That it should be him and not someone else is an arbitrary matter... [9]" (p. 16). Thus he feels justified in his reluctance to respond ethically to strangers in need.

Yet in his consciousness Henry feels guilty of his own selfishness. This predicament mirrors those westerners who stand in the safe place to observe the sufferings of others far away, quite indifferently, lack of empathy. "He feels culpable somehow, but helpless too Culpable in his helplessness.
Helplessly culpable. By daylight, will it seem negligent not to have called the emergency services? Will it be obvious that there was nothing to be done, that there wasn't time? His crime was to stand in the safety of his bed-room... without moving or making a sound, half dreaming as he watched people die... [9] (p. 22) Regarding others' suffering at distance with little empathy, to some degree Henry is selfconscious about his own indifference to strange others who are in need, and feels guilty about his indifference and helplessness.

Actually it turns out that Henry over-interprets the plane accident. The news finally comes out that It's a Russian cargo plane accident due to mechanical problems. Henry's overinterpretation about the accident just mirrors the impact of the traumatic 9//11 attack. And his justification for his exempting himself from the emergency responsibility in his imagination reflects many privileged and selfish westerners whose empathy and care are selected, confined to their loved ones, their family, relatives, friends in their framed world, with little empathy for strangers, particularly for those marginalized others.

Henry's house is framed strongly, “... three stout Banham locks, two black iron bolts as old as the house, two tempered steel security chains, spyhole with a brass cover, the box of electronics that works the Entryphone system, the red panic button, the alarm pad with its softly gleaming digits. Such defences, such mundane embattlement: beware of the city's poor, the drug-addicted, the downright bad. [9]" (p. 37) It is clear that with anxiety Henry is aware that his contented life is under threat of damage from the marginalized persons in the city. As McEwan states in an interview, "Henry Perowne has all the marvelous advantages and yet he finds himself in a state of anxiety - we have all the pleasures and yet we're looking behind our back. And the reason I want to make Perowne a wealthy man is because, actually, that's what the first world is. [1]" In that interview McEwan is also asked "why he has Henry gazing at the locks on his door, thinking about the bad people, the drug dealers who want to get in--there is an embattlement. They are on the other side. You block these people out of your world picture. It's a kind of framing. You cease to see a patient on the table because you only see the little square, the mole----" [1] McEwan agrees that "it's a kind of framing. But great things are achieved within that frame [1]. This framing works like a psychological defensive wall for the privileged People in the first world who intentionally block the Other out of their world picture. To be specific, they just practice selected empathy and care to the loved ones in their framed and safe world. Waking from sleep, looking out of the window Henry watches curiously outside figures crossing the square diagonally "In the lifeless cold, they pass through the night, hot little biological engines with bipedal skills suited to any terrain, endowed with innumerable branching neural networks sunk deep in a knob of bone casing, buried fibers, warm filaments with heir invisible glow of consciousness--these engines devise their tracks [9]". (p. 12) Obviously Henry does not empathize the strangers' existence, just view 
them from a biological and scientific way.

Yet in the post-9/11 age, the privileged people's contented life in their framing world is fragile. Inevitably Henry and his family's ordinary and peaceful life would be troubled by the intrusion of the Other on the March protest day, though Henry does not intend to involve himself in the the public protest against the immanent Iraq war, on this Saturday. He just engages with such private things with selected empathy for his loved ones, as playing squash game with his colleague Jay Strauss, visiting his mother who suffers from Alzheimer in the suburb nurse home, watching his son's music performance and cooking diner for the family reunion, waiting for his daughter back from Paris and his father-in law back from his house in France.

\section{Henry Perowne's Paradoxical Happiness and His Lack of Empathy for the Other}

Henry' contented life in his framing world is not only related to the environment, in which his house is located, but also closely associated with his profession. He is a successful neurosurgeon, feels confident and comfortable in his operation room with a sense of control in the "enclosed world [9]", proud to see inside the skull, to see the brain-"the most complex organ in the known universe [9]" (p. 86) Henry "prides himself" on his speed and accuracy. "He's something of a master in the art-and performed a biopsy for a tumour $n$ the thalamus, a region where it's not possible to operate [9] (p. 6) His expertise at operation of human brain and tight schedule make him has a good sense of control of life. "Perowne was able to exercise almost all of it without damaging any eloquent region. [9]" (p. 10) When he finally came away from the theaters, he wasn't feeling tired at all. He enjoys the egotistical joy, "Henry can't resist the urgency of his case, or deny the egotistical joy in his own skills, or the pleasure he still takes in the relief of the relatives when he comes down from the operation room like a god... Operating never wearies him, once busy within the enclosed world of his firm, the theatre and its ordered procedures and absorbed by the vivid foreshortening of the operating microscope as he follows a corridor to $s$ desired site, he experienced a superhuman capacity, more like a craving, for work" [9]. (p. 10) It is clear that Henry derives his stable sense of identity from his profession. He makes every effort to extend his professional capacity to be useful and to be admired by his patients and colleagues, and enjoys his profession to heart, "He will not be disturbed by distress, his obligation is to be useful. He prides himself on speed and s sleek, wry style [9]. (P. 11) In committee he likes precision, all items addressed and disposed within the set time and to this end he; an effective chairman. His wife Rosoliand, a successful lawyer, also keen on her work, on this Saturday will leave home for work before coming back for the family reunion dinner. Work shapes their life, "It's the tide, the lunar cycle they set their lives by and without it, it can seem, there's nothing,
Henry and Roslind Perowne are nothing. [9]" (p. 23) It seems that the upper middle class couple are mainly shaped by their profession and they enjoy their contented life in the framing and privileged world. Obviously with someone breaking the framing of the profession, Henry's self would be in danger and his contented and happy life is actually fragile.

Is Henry really happy in the post-9/11 age? "No going back. The nineties are looking like an innocent decade, and who would have thought that at the time?Now we breathe a different air. He bought Fred Halliday's book and read in the opening pages what looked like a conclusion and a curse: the New York attacks precipitate a global crisis that would, if we were lucky, take a hundred years to resolve.... [9]" (p. 33) Thus the post-9/11 world of global crisis troubles Henry, with a strong sense of anxiety, yet Henry holds for a while to the idea that "it was all an aberration, that the world would surely calm down and soon be otherwise, that solutions were possible, that reason, being a powerful tool, was irresistible, the only way out; or that like another crisis, this one would fade soon... [9]." (p. 33) Despite the anxiety for the possible destruction of the world, in his scientific and rational view, Henry believes that the world won't easily allow itself to be destroyed. It's good to let go. Life in it has steadily improved over the centuries for most people, despite the junkies and beggars now. On the whole he is optimistic about the city and the world and believes that "Every level, material, medical, intellectual, sensual, for most people is has improved.... everyone he's passing now along this pleasantly down-at heel street looks happy enough, at least as content as he is. [9]" In his scientific and rational perspective, Henry has a complacent and solid belief in the progress of the world and happiness of the middle-upper class.

However, paradoxically in the post-9/11 age for professors in the academy, for the humanities generally, "misery is more amenable to analysis: happiness is a harder nut to crack. [9]" (p. 78) Actually Henry's sense of happiness is also paradoxical. There is doubt about his happiness in his consciousness. On this Saturday after breakfast on his way driving to the squash court, the description about his inner thoughts reveals his authentic emotional state. "He doesn't like himself on this frame, but the second-by-second wash of his thoughts is only partially his to control---the drift, the white noise of solitary thought is driven by his emotional state. Perhaps he isn't really happy at all, he's psyching himself up. [9]" Thus in his authentic state there is paradox in his happiness, perhaps he is not really happy, disturbed by some unfulfilled emotional needs or lack of something that would bring him real happiness. Henry now is parallel to and two blocks south of Warren Street. "He's still bothered by his peculiar state of mind, this happiness cut with aggression. [9]" (p. 78). He begins a familiar routine, listing the recent events that may have shaped his mood. "That he and Rosolind made love, that it's Saturday morning, that this is his car, that no one died in the plane and there is a game ahead...[9]" (p. 78). All this is to be good and the forward motion is a prompt, it instantly returns him to his list, the proximal and distal causes of his emotional state. Thus in his framing and private 
state there is no reason for him to feel unhappy. But he admits that "it is in fact the state of the world that troubles him most, and the marches are there to remind him of it. [9]" (p. 80) In his consciousness he can not deny the fact that "The world probably has changed fundamentally and the matter is being clumsily handled, particularly by the Americans. There are people around the planet, wellconnected and organized, who would like to kill him and his family and friends to a make a point... there will be more deaths on a similar scale, probably in this city. Is he so frightened that he can't face the fact? [9]" (p. 80) With these worries for the threat of terrorism, the happiness Henry experienced is quite paradoxical and he is anxious to know what is wrong with the world, with self-reflection about the deep causes of the 9/11 terrorism. Thus Ian McEwan attempts to reflect about the deep causes of international terrorism from the consciousness of Henry Perowne, an ordinary privileged while man in the first world. Then what happens to Henry in his car scrap with Baxter's car on his driving way to the squash game mirrors the conflict between the first world and the potential terrorism to some degree.

When Henry's car had a scrape with another car on his driving way to the squash game, his first thoughts are concerned with his own car's damage rather than the persons involved in the minor accident, "His car will never be the same again, It's ruinously altered, so is his Saturday... [9]" (p. 82) $\mathrm{He}$ is angry about the unexpected accident that puts his routine peaceful Saturday in disorder, “... just pulled out, no signal, stupid bastard, stupid bastard, didn't even look, what's his mirror for, fucking bastard... [9]" (p. 82). He feels that he hates to confront the person in the car and exchange insurance details when he could be playing squash. "He feels he's been left behind. He even could not believe it is real And he knows that he has to be cautious [9]". (p. 83) Thus after the car scrape Henry's thoughts and concerns are narcissistic, and he shows little empathy about others, even with much arrogance and prejudice against the opponent. The car is a series-five BMW, "a vehicle he associates for no good reason with criminality, drug-dealing [9]." (p. 83) His impulse then is to ignore the men, walk away from them, round the front of the Mercedes to get a view of the damaged side. But even as he stands, with hands on hips, in a pose of proprietorial outrage, he keeps the men, now advancing as a group on the edge of vision. "Without damage of his car, he has nothing to show for his anger [9]". (p. 84) The free indirect speech about Henry's thoughts reveals that Henry's arrogance may easily offend others. Moreover, what happens then shows that "Henry, an expert on the brain, fails to empathize and predict how another might feel; he fails to read Baxter's mind and this endangers his entire family [10]".

Henry is arrogant and condescending in his attitude toward Baxter, the young man involved in the accident. As Baxter offers Henry a cigarette, Henry sees from his perspective "The grippe hand extending toward Perowne is large... the persistent tremor also draws perowne's professional attention. Perhaps there's reassurance to be had in the unsteadiness of the grip. [9]" (p. 87) As Henry pays professional attention to
Baxter's unusual tremor, he does not show any empathy or sympathy for Baxter. Instead, he judges that Baxter's hand suggests "an impression of fretful impatience, of destructive energy waiting to be released [9]". (p. 88) As Baxter first asked Perown, that "I expect you're all ready to tell me how sincerely sorry you are. [9]" (p. 89) Henry says, "I am indeed sorry that you pulled out without looking. [9]" (p. 89) Henry surprises himself. "This fussy, faintly archaic 'indeed' is not generally part of his lexicon. Deploying it entails decisions; he isn't going to pretend to the language of the street. He's standing on professional dignity. [9]" (p. 89) Revealed in Henry's language is his professional and class superiority over Baxter. Baxter replies patiently that he does not need to be looking. The Tottenham Court road is closed and Perowne is not supposed to be there. As they discuss the matter of the damaged wing mirror of Baxter's car, Henry is thinking of his appointment with his colleague to play squash game and wants to settle the matter as soon as possible.

As Henry finds that Baxter wants to charge him with cash, in his eyes Baxter is described this way "The manoeuvring are clumsily deliberate, like an ill-rehearsed children's ballet [9]". (p. 89) His attention settles once again on Baxter's right hand. It isn't simply a tremor, it's a fidgety restlessness implicating practically every muscle. "Speculating about it soothes him [9]". (p. 90) Watching Baxter's behaviour Henry suddenly understands enough about Baxter's disease and says to Baxter dismissively, he will not give cash, and just give him the detailed information about insurance, and adds that he is late for an important meeting. Henry thinks confidently and arrogantly that employing his professional knowledge to give diagnosis of Baxter's brain disease would save him from the trouble of being mugged. However, with little empathy to understand Baxter's mind, Henry is not conscious that he is misusing his medical authority to insult Baxter in front of his companions, "You father has it. Now you've got it too. [9]" (p. 95) Henry thinks Baxter knows the conditions of his father, and he won't have told the companions Nigel or Nark or any of his friends. This is his secret shame. Thus in front of Nigel and Nark, Henry puts Baxter in shame. Baxter orders his friends to stay in the car and talks to Henry about his disease.

Even getting information about Baxter's marginalized living situation, Henry does not show any empathy for Baxter who grows up in a poor situation. Instead he further misuses his professional knowledge to insult Baxter, due to his lack of empathy for Baxter. Inquiring about personal information about Baxter, Henry knows that Baxter's mother is dead, and he lives in his father's old flat, without any schooling. As Henry professionally diagnoses Baxter's illness as incurable Huntington disease of brain, he talks about the medicine that helps with loss of balance, tremors, depression of the patient, he observes that "in this transitional phase of perplexity or sorrow, the vaguely ape-like features are softened, even attractive. [9]" (p. 94) In Henry' eyes, Baxter's face is apelike, subhuman, not a person as equal as himself. "He's an intelligent man and gives the impression that, illness apart, he's missed his chances, made some big mistakes and ended 
up in the wrong company. Probably dropped out of school long ago and regrets it. No parents around And now, what worse situation than this could he find himself in? There's no way out for him. No one can help. But Perown knows himself to be incapable of pity. Clinical experience wrung that from him long ago. And a part of him never ceases to calculate how soon he can safely end this encounter. [9]" (p. 99) Thus Henry is rational enough to employ his professional knowledge for his self protection escaping from a possible mugging rather than giving medical help for Baxter to relieve his suffering from Huntington disease with empathy. Baxter responds to him, "You're trying to fuck with me. In front of those two. You think I care? Well fuck you. I am calling them back. [9]" (p. 99) Actually Baxter is terribly humiliated by Henry in front of his companions. He fails to empathize Bater's mind. Rather he even feels proud of himself for escaping from the potential mugging by misusing his medical authority, "for pride's sake, he does not want to appear hurried. [9]" (p. 100)

Thus Henry's misuse of his medical knowledge saves him from the potential mugging in the minor car accident and has won the edge over Baxter and his companions. However, later in his mind he suffers from the guilty feelings to some degree. Then Henry arrived at the squash courts to meet Jay Strauss, his American colleague, who already waited for him for ten minutes. His explanation about his lateness centered mostly on the scrape itself, skipping the rest, and saying only that it took a while to sort out. "He is conscious that he don't want to talk about Baxter and his friends and he's already feeling a rising unease about the encounter, a disquiet he can't yet define, though guilt is certainly an element [9]." (p. 103) Reflecting on his vulnerable and fragile body he is in a mild shock, anxious about the woulds he may suffer. It seems that he is not interested in playing squash at the moment, "what he really wants is to go home and lie down in the bedroom and think it through, the dispute in University Street and decide how he should have handled it and what it was he got wrong. [9]" (p. 104) But even as he's thinking this, he's pulling on his goggles and stepping onto the court and closing the door behind him. During the game, it is difficult for Henry to focus his attention, guilty of his attitude toward Baxter, "But as the ball floats off the front wall towards him, unwanted thoughts are shaking at his concentration. He sees the pathetic figure of Baxter in the rear-view mirror. [9] (p. 106)"

Henry experiences tension and irritation during his squash contest with Strauss and his encounter with Baxter is a great shadow for him, and reflects about his selfish and arrogant attitudes towards Baxter. "Did he Henry Perowne, act unprofessionally, using his medical knowledge to undermine a man suffering from a neurogegeneratative disorder? Yes. Did the threat of a beating excuse him? Yes, no, not entirely... Okey a fool would stand there and take a kicking when there was a way out. So what's troubling him? Strangely, for all the violence, he almost liked Baxter. That's to put it too strongly. He was intrigued by him, by his hopeless situation, and his refusal to give up. And there was a real intelligence there, and is may that he was living the wrong life. And he, Henry, was obliged, or forced, to abuse his own power---but he allowed himself to be placed in that position. His attitude was wrong from the start, insufficiently defensive; his manner may have seemed pompous, or disdainful. Provocative perhaps. He could have been friendlier, even made himself accept cigarette; he should have relaxed, from a position of strength, instead of, which he was indignant and combative. [9]" (pp. 113-114) Henry is guilty of his attitude towards Baxter but at the same time he justified himself for his behaviour, "On the other hand, there were three of them, they wanted his cash, they were eager for violence, they were planning it before they got out of their car. The loss of a wing mirror was cover for a mugging. [9]" (p. 114.) Quite guilty and uneasy, at the same time he still fails to realize that due to his lack of empathy for Baxter he has severely insulted Baxter which may endanger his family potentially.

Henry's lack of empathy toward Baxter is not only attributed to his arrogance as a privileged neurosurgeon but also is closely related to his poor comprehension of literature. In his education and career what he read bears little with literature. And his poet daughter Daisy has tried to educate him about literature reading. Under Daisy's guidance, Henry has read the whole of Anna Karenina and Madame Bovary at the cost of many hours of his valuable time. "What did he grasp? These books were the products of steady, workmanlike accumulation [9]" (p. 66) As a brain surgeon, Henry is a materialist, "A man who attempts to ease the miseries of failing minds by repairing brains is bound to respect the material world, its limits and what it can sustain-consciousness, no less. [9]” (p. 33) However, Henry's materialist and scientific understanding of brain could not help him have deep understanding of mind, consciousness, which requires much imagination to experience the feelings of the person other than himself. And reading literature does help improve such imagination and empathy. However, so far "Daisy's reading lists for Henry have persuaded him that fiction is too humanly flawed, too sprawling and hit-and-miss to inspire uncomplicated wonder at the magnificence of human ingenuity, of the impossible dazzlingly achieved. [9]" (p. 67) According to Daisy, people can't live without stories, but for Henry it is not true. He is living proof. He responds to his world in terms of observable, measurable truth. He knows his world through science. What Ian McEwan aims to explore is the different and complementary function of science and literature in understanding mind. Obviously Henry's scientific knowledge and poor comprehension of literature make him an expert of brains but a failure to empathize Baxter's mind and his insult for Baxter endangers his whole family soon. Then after Baxter breaking into Henry's house, it is poetry, literature rather than Henry's scientific knowledge that saves the family from violence at the critical moment, and Henry is also awakening to approach his ethical self by extending his empathy to the Other. 


\section{Henry Perowne's Awakening of Ethical Self Through Extending Empathy and Care to the Other}

Later as Henry briefly tells his son Theo about the minor accident, 17-year-old Theo immediately realizes that his father insulted Baxter, and tells his father that he humiliates Baxter and warns him to be careful, "You humiliated him. You should watch that. [9]" (p. 152). Thus Henry's lack of empathy towards Other is obvious. He does not realize that his attitudes and behaviour in his encounter with Baxter terribly humiliated Baxter, which puts all the family under the potential threat of Baxter's violent attack.

In the evening as Baxter holds Henry's wife Rosalind at knifepoint, and intrudes into the house, readers and Theo are not surprised, yet Henry with poor empathy is very shocked. Henry, an expert on the brain, fails to empathize and predict how another might feel; he fails to read Baxter's mind and this endangers his entire family [10]" (Green 64) Baxter's intrusion is metaphoric. Baxter with incurable brain disease is the underprivileged Other wondering in London city, and the conflict between Baxter and Henry is that between the marginalized Other and white privileged self. And the Other's intrusion damaged the framing world of the privileged self, a terrorism on small scale. If Henry has shielded and framed himself and his family from the underprivileged class and social community, Baxter's intrusion breaks the framing and it's then that Henry's ethical self awakens with responsibility towards the Other through his extending of empathy. According to Emmanuel Levinas, the self is "hostage' to and has a "responsibility" for the Other [11]. His finely nuanced theory implies that although the individual is a passive 'hostage' to the Other, one also has an active 'responsibility' to give oneself over to the Other to increase the possibility of overcoming alienation and persecution on personal and social levels. What Levinas attempts to rescue the holiness of the human's ethical existence from selfishness and complacency is similar to what Ian McEwan aims to explore Henry's awakening of ethical self after Baxter's intruding into his house.

Perown's awakening of ethical self with his sense of responsibility towards Baxter, the Other, takes place in the process of Baxter's intrusion into the family. He first did not put himself in the shoes of Baxter earlier to empathize Baxter's misery to understand Baxter's mind, and only when Baxter invades his family and the whole family in danger does Henry, together with his family strain to read Baxter's mind, "the separating minds of Henry, Rosalind, Theo, Daisy, and Grammaticus work together for their survival [10]" Henry's first attempts to understand Baxter's mind to save his family from Baxter's attack turns out to fail, with his father- in law, Grammatical's nose broken to blood by Baxter.

It is literature in the form of poetry rather than Henry's scientific knowledge that thwarts Baxter's violence and Henry's ethical awareness is awakened through the extension of his empathy in the process. As Baxter forced Daisy to take off her clothes in front of the family, he was bewildered by Daisy' pregnant body. Viewing poetry on the table, Baxter orders Daisy to read her best poetry. The grandfather, the once well-known poet hints Daisy to read Matthew Arnold's famous poem "Dover Beach". Henry does not know Arnold, fails to recognize the deep meaning of the poem. Still as he listens to the poem, Henry's empathy is enriched. He first imagines Daisy and her lover in the poem, "He sees Daisy on a terrace overlooking a beach in summer moonlight... she calls to her lover, surely the man who will one day father her child, to come and look, or, rather, listen to the scene. Perowne sees a smooth skinned young man, naked to the waist, standing at Daisy' side... She turns to him, and before they kiss she tells him that they must love each other and be faithful, especially now they're having a child, and when there's no peace or certainty, and when desert armies stand ready to fight [9]. (p. 229) In Henry's imagination Daisy and his lover confronts the dark and violent world bravely. Though appreciating poetry improves Henry's imagination and empathy but he just confines his empathy to his loved ones and according to the resources and conditions with which he is familiar to comprehend the poem. He only empathize his loves ones who are in the disorder.

As Baxter asks Daisy to read the poem again, Henry listens to the poem again, and his empathy for others is extended from his loved ones to the Other, Baxter. This time in Henry's imagination the figures in the poem is not Daisy and her lover but Baxter, "Instead he sees Baxter standing alone, elbows propped against the sill, listening to the waves 'bring the eternal note of sadness in. '... Then once again, it's through Baxter's ears that he hears the sea's 'melancholy, long withdrawing roar, retreating, to the breath of the night wind, down the vast edges drear and naked shingles of the world. 'It rings like a musical curse. The plea to be true to one another sounds hopeless in a absence of joy or love or light or peace or 'help for pain"' [9]" (p. 230) Thus Henry puts himself in the shoes of Baxter, a poor person with incurable disease, to comprehend what the poem means. Ignorant of the cultural context of the poem, Henry fails to understand what Arnold aims to express. However, in the process of his interpretation of the poem, Henry extends his empathy for others and reserved the room to imagine what others' life is alike, even for the invader, Baxter. Thus Henry finally steps out of his arrogant and framing vision to experience the existence of the Other, another person different from his own existence. It is this ambiguity and uncertainty of literature that enrich Henry's empathy and care for others.

On the other hand, what Baxter has appreciated about the poem is foreign to Henry himself, which also reminds Henry of the fact that he should be humble to preserve his awe and respect for others. Baxter's appreciation of the poem is unique and his swing mood of violence seems to be checked, and asks Daisy to read it again, "Baxter appears suddenly elated. His right hand has moved away from Rosolind's shoulder and the knife is already back in his pocket. [9]" (p. 230) Baxter is saying excitedly, "You wrote that. You wrote 
that. [9]" (p. 231) Despite the ignorance of Dover Beach, Baxter has his unique aesthetic experience of the poem and says excitedly, "It's beautiful. You know that, don't you. It's beautiful. And you wrote it. [9]" (p. 232) and he further says, "It makes me think about where I grew up. [9]" (p. 231) And he repeated several times "you wrote it! [9]" Thus Baxter transforms from a lord of terror to an amazed admirer. He gives up his attempt to rape Daisy. At the critical moment of life and death for Henry's family, It's artistic beauty of "Dover Beach" rather than Henry's scientific knowledge that brings a good turn for the dangerous situation. Henry could not feel the beauty that Baxter appreciates about the poem, and this reminds him that he should respect the Other. Henry is on his way to transcend his conventional and narrow existence through extending his empathy to more diverse others besides his loved and the people of his class. In this process, Daisy's rereading of Victorian "Dover Beach" plays an important role in making it possible for Baxter to give up his violent attempt and for Henry to extend his empathy on his way to approach his ethical self, which also indicates Saturday is "a novel about heritage and inheritance [12]".

Henry does not approach his ethical self until he has experienced the face of Baxter. And "face" is an important concept for Levinas. Other's face is the starting place for ethics. Levinas writes: "The approach to the face is the most basic mode of responsibility... The face is not in front of me, but above me; it is the other before death, looking through and exposing death. Secondly, the face is the other who asks me not to let him die alone, as if to do so were to become an accomplice in his death. Thus the face says to me: you shall not kill. [13]" (p. 131-132) Thus according to Levinas, the face of the Other makes an ethical demand on the self. After Baxter's appreciation of beauty of the poem, he is eager to know the information how to cure his disease and asks Henry about the trial. Henry lies that the stuff is in the office upstairs. As Henry and Theo fling Baxter down the stair, gravely injuring Baxter, "There is a moment, which seems to unfold and luxuriously expand, when all goes silent ans still, when Baxter is entirely airborne, suspended in time, looking directly at Henry with an expression, not so much of terror, as dismay [9]" (p. 236) And it's on Baxter's "face" that "Henry thinks he sees in the wide brown eyes a sorrowful accusation of betrayal. He, Henry Perowne, possesses so much--- the work, money, status, the home, above all, the family---... and he has done nothing, given nothing to Baxter who has so little that is not wrecked by his defective gene, and who is soon to have even less. [9]" (p. 236) When Henry first encounters Baxter in the car accident he just see subhuman features in Baxter's eyes, but now from Baxter's face, Henry sees the call of ethical response, it's an ethical responsibility evoked in the vulnerable Other's face. Levinas writes, " the face of the other in its precariousness and defenselessness, is for me at once the temptation to kill and the call to peace, the 'You shall not kill' [13]" To respond to the face, to understand its meaning, means to be awake to what is precarious and defenseless in another life. Thus confronting Baxter's defenseless face, Henry is awakening to his ethical self with responsibility for the Other.

Henry finally decides to go back to the hospital to operate for Baxter's damaged brain, and he explains to his wife, "I have to see this through, I am responsible. [9]" (p. 245) He knows that his abuse of his medical authority to insult Baxter is responsible for Baxter's later intruding into his house. Henry persuades his family to give up the charge for Baxter. His operation for Baxter is successful. In the process of the operation he is fully absorbed in the operation "For the past two hours he's been in a dream of absorption that has dissolved all sense of time, and all awareness of the other parts of his life. Even his awareness of his own existence has vanished. He's been delivered into a pure present, free of the weight of the past or any anxieties about the future. In retrospect, though never at the time, it feels like profound happiness... [9]" (p. 266) It is in the complete absorption in the present during the operation that Henry reaches the ethical self and experiences the profound happiness. Thus the encounter with Baxter the Other, makes it possible for Henry to awaken from his framing and complacent existence with selected empathy and care only for his loved ones to approach his ethical self assuming responsibility for the Other through extending empathy and care to more diverse others.

\section{Conclusion}

Saturday describes a 24-hour slice of the life of Henry Perowne, a 48-year-old British neurosurgeon, after he wakes early on Saturday morning in February 2003 to view a burning airplane in the night sky over London. The novel communicates " its political themes in terms of family life, celebrates the power of the novel to explore both pathological and political states of mind and draws on uncanny politicizing effects in representing the everyday. [14]". From Henry's consciousness the rich narrative set in the post-9/11 London, weaves the story of his contented and paradoxically happy life together with his anxiety about the terrorism implied in his over-interpretation of the burning airplane against the back drop of London March against the immanent Iraq war, his encounter with Baxter in a minor car accident and later Baxter's breaking into his house to endanger his family. As Elaine Hadley writes that in Saturday McEwan defines his protagonist as a self-reflexive agent, capable of thinking about the world beyond --about an abstract totality--but also, signally, capable of and habitually prone to thinking about his thinking of that world. [15]" Henry is a thoughtful and self-reflective agent, representative of the privileged self in the first world. Ian McEwan states in an interview about Saturday that "It's a novel that attempts to hold up to a troubled time. [1]" In the post-9/11 age of anxiety, Henry the self-reflexive neurosurgeon, complacent and contented in his framing world, originally only with selected empathy and care for his loved ones finally awakens to approach his ethical self with responsibility for the Other. Daisy's rereading of "Dover Beach" plays an important role in making it possible for Baxter to give up his violent attempt 
and for Henry to extend his empathy on his way to approach his ethical self, thus McEwan "provides a rather optimistic view of the power of literature [16]". As Wells argues, "The final confrontation plays out a scenario of domestic terrorism that ends with the invader subdued, implying that the text sanctions the right of the dominant culture to defend itself aggressively." [17] It's his encounter with Baxter the Other and Baxter's breaking into his framing world that makes it possible for Henry to approach his ethical self achieving profound happiness in his inner heart through extending his empathy and care to the Other beyond his loved families and colleagues. What Ian McEwan explores in Saturday is an ethical attempt for privileged Westerners to reflect about the deep causes of international terrorism and to sort out the conflicts between self and the Other in an ethical way with the prospect of experiencing profound happiness through extending empathy and care to more diverse others beyond his framing world in the post-9/11 age of anxiety.

\section{Acknowledgements}

This article is funded by Jiang Su Social Science Fund of the Project of a Study of Ethics of Empathic Care in Ian McEwan's Novels (16WWD004).

\section{References}

[1] McEwan, Ian. Conversations with Ian McEwan. Ed. Ryan Roberts. Mississippi: UP of Mississippi, 2010: ix, 123.

[2] Mellors, John. "Five Good Novels", The Listener, 28 September 1978: 410.

[3] Walkowitz, Rebecca L. "Ian McEwan." A Companion to the British and Irish Novel, 1945-2000. Ed. Brian W. Shaffer. Malden, MA: Blackwell, 2005: 504.

[4] McEwan, Ian. "Only Love and Then Oblivion. Love was All They Had to Set Against Their Murderers", The Guardian, 12 September 2001.
[5] Kohut, Heinz, How does analysis cure? Kohut, Heinz. Chicago, IL: University of Chicago Press, 1984: 82.

[6] Coplan, Amy and Peter Goldie. Empathy: Philosophical and Psychological Perspectives. Oxford: Oxford P, 2011: ix.

[7] Head, Dominic. Ian McEwan. Manchester: Manchester UP, 2008: 192.

[8] Möller, Swantje. Coming to Terms with Crisis: Disorientation and Reorientation in the Novels of Ian McEwan. Heidelberg: Universitätsverlag Winter, 2011: 146.

[9] McEwan, Ian. Saturday. London: Jonathan Cape, 2005.

[10] Green, Susan. "Consciousness and Ian McEwan's Saturday: What Henry Knows.” English Studies, 91.1 (February 2010): 58-73. $(64,66)$

[11] Peperzak, Adriaan. To the Other: An Introduction to the Philosophy of Emmanuel Levinas. West Lafayette: Purdue UP, 1993: 26.

[12] Hillard, Molly Clark Hillard. - "When Desert Armies Stand Ready to Fight": Re-Reading McEwan's Saturday and Arnold's "Dover Beach" - Partial Answers: Journal of Literature and the History of Ideas 6: 1 .

[13] Emmanuel Levinas, Ethics and Infinity, trans. Richard A. Cohen, Pittsburgh: Duquesne University Press, 1985: 87.

[14] Brown, Richard. "Politics. the Domestics and the Uncanny Effects of the Everyday in Ian McEwan's Saturday. " Critical Survey. 2008: 80-93.

[15] Hadley, Elaine. "On a Darkling Plain: The Fantasy of Liberal Agency," Forum on Liberalism, Victorian Studies, Autumn 2005, 92-102.

[16] Martiny, Erik. "A Darker Longing": Shades of Nihilism in Contemporary Terrorist Fiction" Anglistik und Englischunterricht. 2009, Vol 73: 159-172.

[17] Wells, Lynn. "Moral Dilemma" in The Cambridge Companion Ian McEwan. edit. Dominic Head. Cambridge: University Printing House. 2019: 29-44. 